Hydraulic Engineering Repository

Ein Service der Bundesanstalt für Wasserbau

Sheppard, Max D.; Miller, William

Live-Bed Local Pier Scour Experiments

Verfügbar unter / Available at:

https://hdl.handle.net/20.500.11970/99970

Vorgeschlagene Zitierweise / Suggested citation:

Sheppard, Max D.; Miller, William (2004): Live-Bed Local Pier Scour Experiments. In: Chiew, Yee-Meng; Lim, Siow-Yong; Cheng, Nian-Sheng (Hg.): Proceedings 2nd International Conference on Scour and Erosion (ICSE-2). November 14.-17., 2004, Singapore. Singapore: Nanyang Technological University. 


\title{
LIVE-BED LOCAL PIER SCOUR EXPERIMENTS
}

\author{
D. MAX SHEPPARD \\ Civil and Coastal Engineering Department, University of Florida, 365 Weil Hall \\ Gainesville, Florida 32611, US \\ WILLIAM MILLER JR \\ Taylor Engineering, 9000 Cypress Green Drive, Suite 200, Jacksonville, Florida 32256, US
}

\begin{abstract}
Local clear-water and live-bed scour tests were performed at the Hydraulics Laboratory at the University of Auckland in Auckland, New Zealand for a range of water depths and flow velocities with two different uniform cohesionless sediment diameters $(0.27$ and $0.84 \mathrm{~mm})$ and a circular pile with a diameter of $0.15 \mathrm{~m}$. These tests extend local scour data obtained in controlled experiments to velocity ratio $(\mathrm{V} / \mathrm{Vc})$ values as high as 6 (near the live-bed peak scour velocity). The results of these tests validate the local equilibrium scour depth prediction algorithm developed by the lead author. The algorithms of Breuser et al. (1977), Melville and Coleman (2000) and Richardson and Davis (2001) are also reviewed and a comparison is made between the four predictions and the test data. Several hypothetical prototype scale conditions are then examined using all four algorithms to illustrate the differences in the predictions at prototype scale. The four predictive equations are also compared for a prototype bridge pier where the scour depth is known.
\end{abstract}

\section{Introduction}

This paper presents the results of 24 local sediment scour experiments conducted by the lead author in the Hydraulics Laboratory at the University of Auckland in Auckland, New Zealand. The tests were performed with a single circular pile located in two different, uniform diameter cohesionless sediments, with a range of water depths and flow velocities. All but four of the tests were conducted in the live-bed scour range. The scour depth results and sample time history plots of the scour depth are presented in this paper. The reader is referred to the technical report by Sheppard (2003a) for additional data and details of the analyses.

Equilibrium scour depth predictions using Sheppard's and three additional commonly used equations are made and compared to the measured data. Finally, the four equations are used to predict equilibrium scour depths for several hypothetical prototype scale situations and the results compared.

A number of researchers have observed two scour depth maximums (scour peaks) when plotting normalized scour depth, $\mathrm{d}_{\mathrm{se}} / \mathrm{D}$, versus $\mathrm{V} / \mathrm{V}_{\mathrm{c}}$ (Ettema 1980; Chiew 1984; Melville and Chiew 1999, Sheppard 1998). One maximum occurs at the transition from clear-water to live-bed scour conditions and one in the live-bed scour range. The livebed maximum is thought to occur at the flow velocity where the bed "planes out". The velocity at the second peak is referred to here as the "live-bed peak velocity" and is 
denoted by $\mathrm{V}_{\mathrm{lp}}$. This velocity can be estimated using van Rijn's equations for determining plane bed velocity (van Rijn 1993, pp. 5.3-5.4).

\section{Live-Bed Local Scour Tests}

Live-bed local sediment scour tests were performed on a circular pile with a diameter of $0.152 \mathrm{~m}$ and with sediments with median grain sizes of $0.27 \mathrm{~mm}$ and $0.84 \mathrm{~mm}$. The sediment size distributions were near uniform with standard deviations $(\sigma)$ of 1.33 for the $0.27 \mathrm{~mm}$ sediment and 1.32 for the $0.84 \mathrm{~mm}$ sediment.

\subsection{Experimental Facilities}

All tests were conducted in a tilting flume located in the Hydraulics Laboratory in the Civil and Environmental Engineering Department at the University of Auckland in Auckland, New Zealand. The flume is $1.5 \mathrm{~m}$ wide, $1.2 \mathrm{~m}$ deep, and $45 \mathrm{~m}$ long and has two pumps for recirculating the water with a combined capacity of $1.2 \mathrm{~m}^{3} / \mathrm{s}$. The bed load sediment is trapped and pumped to the flume entrance as a slurry with a sediment pump. Suspended sediment is pumped with the water to the entrance with either or both of the water pumps.

\subsection{Instrumentation}

The flow parameters measured were flow discharge (indirectly), velocity at specific locations, and water depth, and temperature. The bed and water elevations at the walls of the flume at the test section were monitored with externally mounted cameras for most of the live-bed tests. The scour depth was monitored with miniature video cameras located inside the cylinder on a vertical traversing mechanism and with arrays of acoustic transponders mounted on the outside of the cylinder.

\subsection{Experimental Procedure}

In order to insure repeatability and to isolate the effects of various parameters on equilibrium scour depth and rate of scour, a strict procedure was followed throughout these tests. A summary of the experimental procedure used is outlined below. The procedure is divided into the tasks performed before, during, and after each experiment.

Pre-experiment:

(1) Compact and level the bed in the flume.

(2) Fill the flume slowly and allow to stand until the air trapped in the sediment has escaped.

(3) Take pre-experiment photographs.

During experiment:

(4) Measure the scour depth as a function of time with acoustic transponders and video cameras. 
(5) Measure the velocity, water depth, and temperature.

(6) Monitor bed elevation at flume walls in test section with external video cameras.

(7) Monitor bed forms during live-bed tests.

Post-experiment:

(8) Take post-experiment photographs.

(9) Observe and note bed condition throughout the flume (presence of bed forms, etc.).

(10) Survey the scour hole with a point gauge.

(11)Reduce and analyze the data.

\section{Experimental Results}

A significant quantity of local sediment scour data and bed form information were gathered during these experiments. Though most of the tests were performed in the livebed scour range, a few tests were conducted in the clear-water scour range to fill gaps in existing data. The structure, sediment and flow conditions for each experiment are summarized in Table 1. The values of relevant non-dimensional parameters and scour depth data are given in Table 2.

The duration of each test in minutes is listed in Column 9 of Table 1 (labeled "Time"). All of the experiments were relatively long in duration for live-bed scour tests. Thus the scour depths were at or near equilibrium at the end of each live-bed test. An estimate of the maximum scour depth reached (with bed form effects removed) is given in Column 6 of Table 2 (labeled "Max d $\mathrm{d}_{\mathrm{s}}$ ).

Two different mathematical functions were used to fit the local scour time history data.

$$
\begin{aligned}
\mathrm{d}_{\mathrm{s}}(\mathrm{t}) & =\mathrm{a}\left[1-\frac{1}{(1+\mathrm{abt})}\right]+\mathrm{c}\left[1-\frac{1}{(1+\mathrm{cdt})}\right], \text { and } \\
\mathrm{d}_{\mathrm{s}}(\mathrm{t}) & =\mathrm{a}[1-\exp (-\mathrm{bt})]+\mathrm{c}[1-\exp (-\mathrm{dt})],
\end{aligned}
$$

where $d_{s}$ is scour depth, $t$ is time and a, b, c and d are curve fit coefficients.

The equation that produced the best least squares fit to the data was used to obtain the equilibrium scour depths for the tests. Once the coefficients in Equations 1 or 2 were determined, time was set equal to infinity to obtain the equilibrium depth. In order to produce accurate estimates of equilibrium scour depths, the authors have found that the duration of the test must be at least that recommended by Melville and Chiew (1999) (i.e. the rate of scour should be less than $5 \%$ of pile diameter in a 24 hour period.

Column 7 in Table 2 (labeled " $\mathrm{d}_{\mathrm{se}}$ ") lists the values of the equilibrium scour depths determined from Equations 1 and 2. Fig. 1 is an example scour depth vs. time plot with the fit curve used to estimate the equilibrium scour depth recorded in Table 2. The bedforms were removed from the equilibrium scour depths presented in Table 2 . 


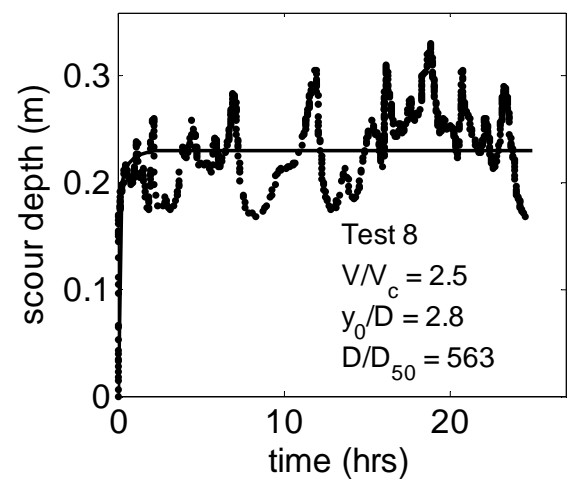

Figure 1. Time history plot of scour depth for Test No. 8 showing data curve fit.

Table 1. Structure, sediment and flow test conditions.

\begin{tabular}{ccccccccc}
\hline \hline Test & $\begin{array}{c}\mathrm{D} \\
(\mathrm{m})\end{array}$ & $\begin{array}{c}\mathrm{D}_{50} \\
(\mathrm{~mm})\end{array}$ & $\begin{array}{c}\mathrm{T} \\
(\mathrm{C})\end{array}$ & $\begin{array}{c}\mathrm{y}_{0} \\
(\mathrm{~m})\end{array}$ & $\begin{array}{c}\mathrm{V} \\
(\mathrm{m} / \mathrm{s})\end{array}$ & $\begin{array}{c}\mathrm{V}_{\mathrm{c}} \\
(\mathrm{m} / \mathrm{s})\end{array}$ & $\begin{array}{c}\mathrm{V}_{\text {lp }} \\
(\mathrm{m} / \mathrm{s})\end{array}$ & $\begin{array}{c}\text { Time } \\
(\mathrm{min})\end{array}$ \\
\hline 1 & 0.152 & 0.27 & 25 & 0.42 & 0.17 & 0.27 & 1.62 & 1740 \\
2 & 0.152 & 0.27 & 22 & 0.42 & 0.62 & 0.28 & 1.62 & 307 \\
3 & 0.152 & 0.27 & 24 & 0.43 & 0.88 & 0.28 & 1.64 & 442 \\
4 & 0.152 & 0.27 & 23 & 0.4 & 1.1 & 0.28 & 1.58 & 465 \\
$5 \mathrm{~A}$ & 0.152 & 0.27 & 23 & 0.4 & 1.26 & 0.28 & 1.58 & 257 \\
$5 \mathrm{~B}$ & 0.152 & 0.27 & 24 & 0.4 & 1.43 & 0.27 & 1.58 & 94 \\
6 & 0.152 & 0.27 & 24 & 0.4 & 1.64 & 0.27 & 1.58 & 104 \\
$7 \mathrm{~A}$ & 0.152 & 0.27 & 24 & 0.2 & 0.55 & 0.25 & 1.25 & 103 \\
$7 \mathrm{~B}$ & 0.152 & 0.27 & 24 & 0.2 & 0.72 & 0.25 & 1.25 & 67 \\
8 & 0.152 & 0.27 & 23 & 0.43 & 0.69 & 0.28 & 1.64 & 1470 \\
9 & 0.152 & 0.27 & 23 & 0.49 & 0.25 & 0.28 & 1.75 & 2760 \\
10 & 0.152 & 0.84 & 23 & 0.43 & 0.37 & 0.41 & 1.89 & 1130 \\
11 & 0.152 & 0.84 & 25 & 0.38 & 0.58 & 0.41 & 1.86 & 3053 \\
12 & 0.152 & 0.84 & 25 & 0.38 & 0.74 & 0.41 & 1.86 & 1019 \\
13 & 0.152 & 0.84 & 26 & 0.38 & 1.05 & 0.41 & 1.86 & 966 \\
14 & 0.152 & 0.84 & 23 & 0.38 & 1.21 & 0.41 & 1.85 & 101 \\
15 & 0.152 & 0.84 & 26 & 0.38 & 1.37 & 0.41 & 1.86 & 60 \\
16 & 0.152 & 0.84 & 26 & 0.38 & 1.52 & 0.41 & 1.86 & 60 \\
17 & 0.152 & 0.84 & 23 & 0.3 & 1.52 & 0.4 & 1.79 & 65 \\
18 & 0.152 & 0.84 & 23 & 0.3 & 1.76 & 0.4 & 1.79 & 75 \\
19 & 0.152 & 0.84 & 24 & 0.3 & 1.85 & 0.4 & 1.80 & 30 \\
20 & 0.152 & 0.84 & 24 & 0.3 & 1.99 & 0.4 & 1.80 & 20 \\
21 & 0.152 & 0.84 & 24 & 0.3 & 2.16 & 0.4 & 1.80 & 20 \\
22 & 0.152 & 0.84 & 18 & 0.43 & 0.25 & 0.41 & 1.87 & 19920 \\
\hline \hline
\end{tabular}


Table 1. Non-dimensional parameters and measured and extrapolated scour depths.

\begin{tabular}{cccccccc}
\hline \hline Test & $\mathrm{y}_{0} / \mathrm{D}$ & $\mathrm{V} / \mathrm{V}_{\mathrm{c}}$ & $\mathrm{D} / \mathrm{D}_{50}$ & $\mathrm{~V}_{\mathrm{lp}} / \mathrm{V}_{\mathrm{c}}$ & $\begin{array}{c}\text { Max. } \\
\mathrm{d}_{\mathrm{s}}(\mathrm{m})\end{array}$ & $\mathrm{d}_{\mathrm{se}}(\mathrm{m})$ & $\mathrm{d}_{\mathrm{se}} / \mathrm{D}$ \\
\hline 1 & 2.8 & 0.6 & 563 & 6.0 & 0.11 & 0.13 & 0.9 \\
2 & 2.8 & 2.2 & 563 & 5.8 & $0.22^{\mathrm{a}}$ & 0.22 & 1.4 \\
3 & 2.8 & 3.1 & 563 & 5.8 & $0.24^{\mathrm{a}}$ & 0.24 & 1.6 \\
4 & 2.6 & 3.9 & 563 & 5.6 & $0.25^{\mathrm{a}}$ & 0.25 & 1.6 \\
$5 \mathrm{~A}$ & 2.6 & 4.5 & 563 & 5.6 & $0.27^{\mathrm{a}}$ & 0.27 & 1.8 \\
$5 \mathrm{~B}$ & 2.6 & 5.3 & 563 & 5.9 & $0.27^{\mathrm{a}}$ & 0.27 & 1.8 \\
6 & 2.6 & 6.1 & 563 & 5.9 & $0.30^{\mathrm{a}}$ & 0.30 & 2.0 \\
$7 \mathrm{~A}$ & 1.3 & 2.2 & 563 & 5.0 & 0.18 & 0.18 & 1.2 \\
$7 \mathrm{~B}$ & 1.3 & 2.9 & 563 & 5.0 & $0.22^{\mathrm{a}}$ & 0.22 & 1.4 \\
8 & 2.8 & 2.5 & 563 & 5.8 & $0.23^{\mathrm{a}}$ & 0.23 & 1.5 \\
9 & 3.2 & 0.9 & 563 & 6.3 & 0.14 & 0.15 & 1.0 \\
10 & 2.8 & 0.9 & 181 & 4.6 & 0.20 & 0.24 & 1.6 \\
11 & 2.5 & 1.4 & 181 & 4.5 & $0.17^{\mathrm{a}}$ & 0.17 & 1.1 \\
12 & 2.5 & 1.8 & 181 & 4.5 & $0.25^{\mathrm{a}}$ & 0.25 & 1.6 \\
13 & 2.5 & 2.6 & 181 & 4.5 & $0.25^{\mathrm{a}}$ & 0.25 & 1.6 \\
14 & 2.5 & 3.0 & 181 & 4.5 & $0.23^{\mathrm{a}}$ & 0.23 & 1.5 \\
15 & 2.5 & 3.3 & 181 & 4.5 & $0.25^{\mathrm{a}}$ & 0.25 & 1.6 \\
16 & 2.5 & 3.7 & 181 & 4.5 & $0.26^{\mathrm{a}}$ & 0.26 & 1.7 \\
17 & 2.0 & 3.8 & 181 & 4.5 & $0.26^{\mathrm{a}}$ & 0.26 & 1.7 \\
18 & 2.0 & 4.4 & 181 & 4.5 & $0.26^{\mathrm{a}}$ & 0.26 & 1.7 \\
19 & 2.0 & 4.6 & 181 & 4.5 & $0.27^{\mathrm{a}}$ & 0.27 & 1.8 \\
20 & 2.0 & 5.0 & 181 & 4.5 & $0.28^{\mathrm{a}}$ & 0.28 & 1.8 \\
21 & 2.0 & 5.4 & 181 & 4.5 & $0.30^{\mathrm{a}}$ & 0.30 & 2.0 \\
22 & 2.8 & 0.6 & 181 & 4.6 & 0.16 & 0.20 & 1.3 \\
\hline \hline
\end{tabular}

${ }^{a}$ measured values at the end of the test with bed forms removed 
Values of equilibrium scour depth for the clear-water scour tests are conservative due to the properties of the fit curves and the extrapolation method used. Some of the live-bed tests were continuations of the previous test, i.e. once an equilibrium scour depth was reached the flow discharge was increased and a new equilibrium depth achieved. This was done for Tests 5A, 5B, 7A, 7B, 15, 16, 18, 19, 20 and 21.

The extrapolated equilibrium scour depths are presented in normalized scour depth, $d_{s e} / D$, versus $V / V_{c}$ plots along with prediction curves (using Sheppard's Equations) in Figs. (1) and (2).

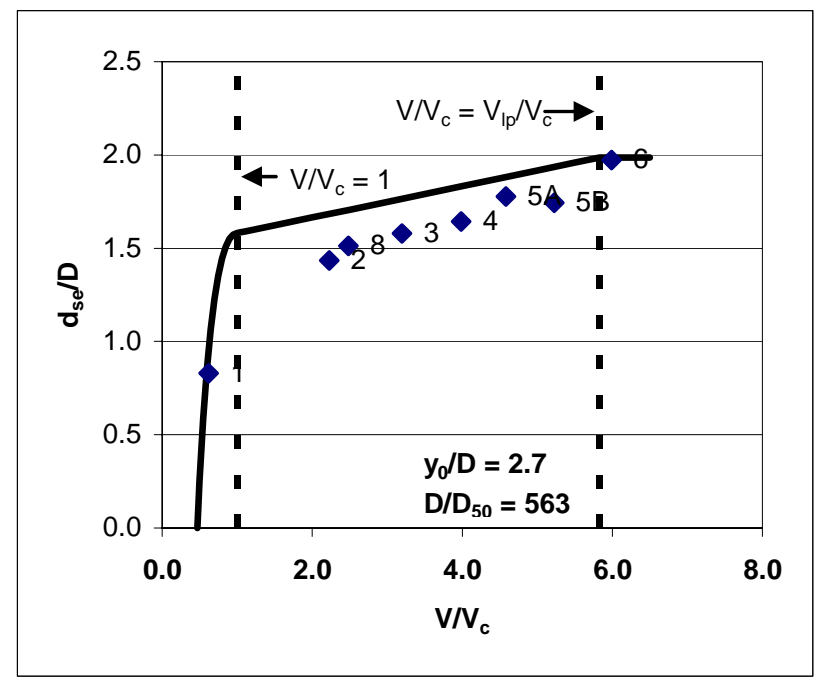

(a)

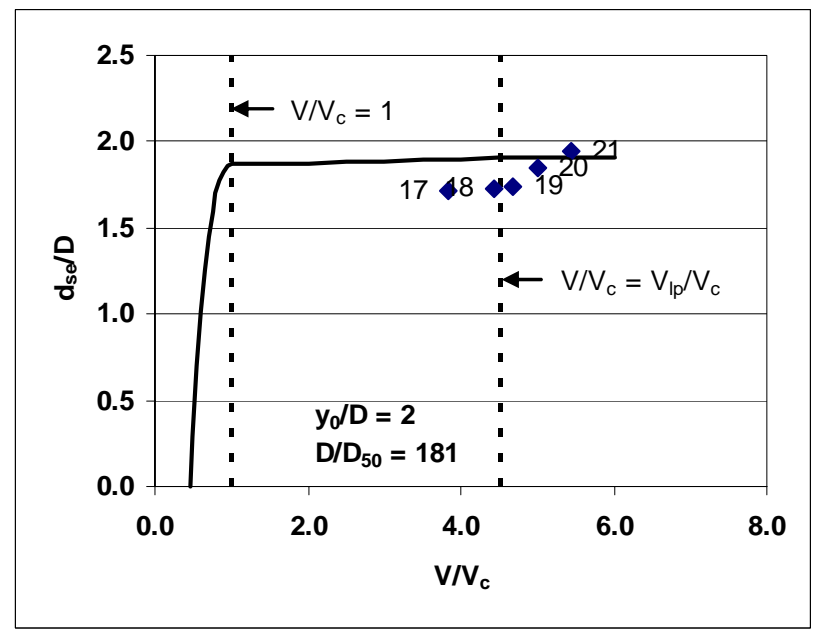

(b)

Figure 2. Predicted (Sheppard's Equations) and measured normalized scour depths. 


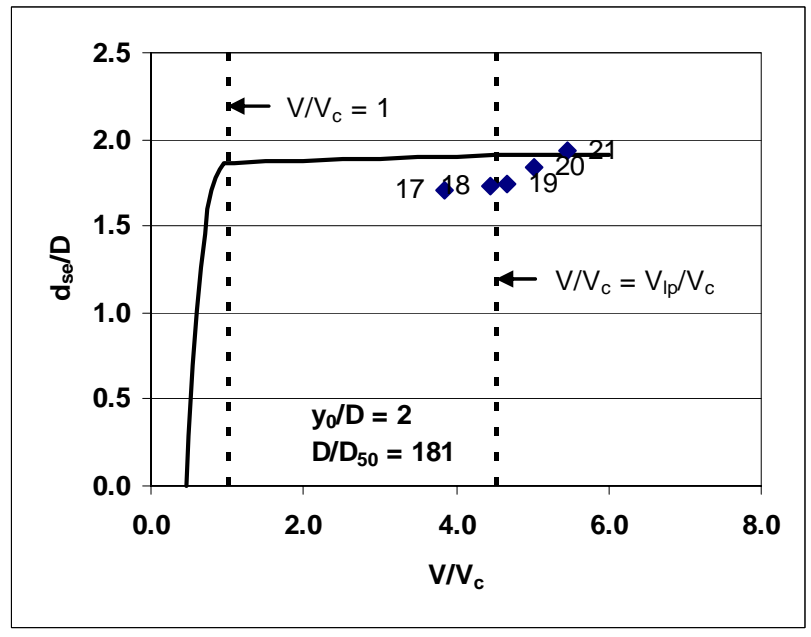

(a)

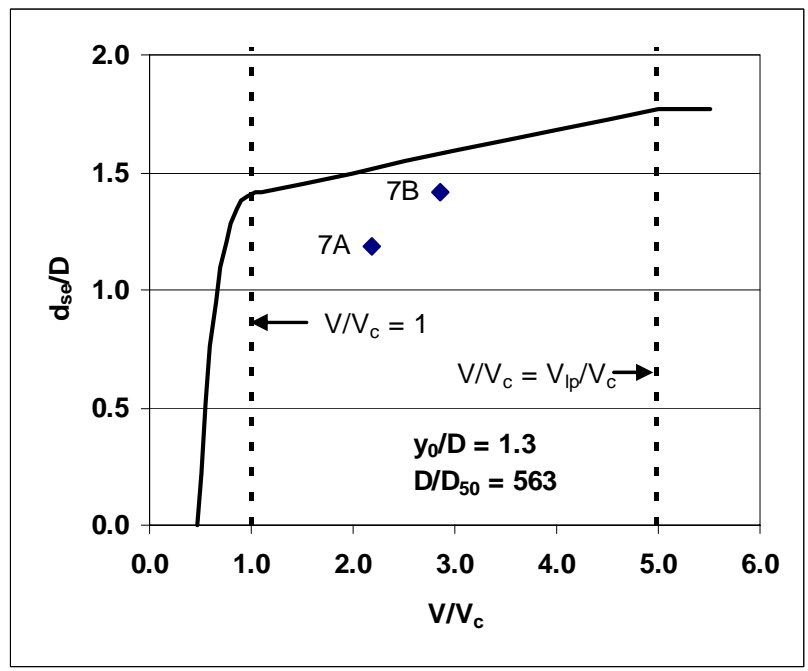

(b)

Figure 3. Predicted (Sheppard's Equations ) and measured normalized scour depths.

\section{Comparison of Four Predictive Equations}

There are many equilibrium scour depth predictive equations in the literature. Due to space limitations only four equations were selected for this comparison [Sheppard (2003a), CSU (Richardson and Davis 2001), Melville (1997), and Breusers et al. (1977)].

Sheppard's Equations

In the clear-water scour range $\left(0.47 \leq \mathrm{V} / \mathrm{V}_{\mathrm{c}} \leq 1\right)$ : 


$$
\frac{d_{\text {se }}}{D^{*}}=2.5 f_{1}\left(\frac{y_{0}}{D^{*}}\right) f_{2}\left(\frac{D^{*}}{D_{50}}\right)\left\{1-1.75\left[\ln \left(\frac{\mathrm{V}}{V_{c}}\right)\right]^{2}\right\}
$$

In the live-bed scour range up to the live-bed peak $\left(1<\mathrm{V} / \mathrm{V}_{\mathrm{c}} \leq \mathrm{V}_{\mathrm{lp}} / \mathrm{V}_{\mathrm{c}}\right)$

$$
\frac{\mathrm{d}_{\mathrm{se}}}{\mathrm{D}^{*}}=\mathrm{f}_{1}\left(\frac{\mathrm{y}_{0}}{\mathrm{D}^{*}}\right)\left[2.2\left(\frac{\mathrm{V} / \mathrm{V}_{\mathrm{c}}-1}{\mathrm{~V}_{\mathrm{lp}} / \mathrm{V}_{\mathrm{c}}-1}\right)+2.5 \mathrm{f}_{2}\left(\frac{\mathrm{D}^{*}}{\mathrm{D}_{50}}\right)\left(\frac{\mathrm{V}_{\mathrm{lp}} / \mathrm{V}_{\mathrm{c}}-\mathrm{V} / \mathrm{V}_{\mathrm{c}}}{\mathrm{V}_{\mathrm{lp}} / \mathrm{V}_{\mathrm{c}}-1}\right)\right]
$$

and in the live-bed scour range above the live-bed peak $\left(\mathrm{V} / \mathrm{V}_{\mathrm{c}}>\mathrm{V}_{\mathrm{lp}} / \mathrm{V}_{\mathrm{c}}\right)$

$$
\frac{d_{\text {se }}}{D^{*}}=2.2 f_{1}\left(\frac{y_{0}}{D^{*}}\right)
$$

where

$$
\begin{gathered}
\mathrm{f}_{1}\left(\frac{\mathrm{y}_{0}}{\mathrm{D}^{*}}\right)=\tanh \left[\left(\frac{\mathrm{y}_{0}}{\mathrm{D}^{*}}\right)^{0.4}\right] \\
\mathrm{f}_{2}\left(\frac{\mathrm{D}^{*}}{\mathrm{D}_{50}}\right)=\frac{\mathrm{D}^{*} / \mathrm{D}_{50}}{0.4\left(\mathrm{D}^{*} / \mathrm{D}_{50}\right)^{1.2}+10.6\left(\mathrm{D}^{*} / \mathrm{D}_{50}\right)^{-0.13}} .
\end{gathered}
$$

In Equations 3 through $7, D^{*}$ is the effective circular pile diameter and $d_{s e} / D^{*}$ is the normalized equilibrium scour depth. If the pile is some shape other than circular, $\mathrm{D}^{*}$ is the diameter of an equivalent circular pile. This is defined as the diameter of the circular pile that will experience the same equilibrium scour depth for the same flow and sediment conditions as the non-circular pile of concern. Since the pile for the tests presented here was circular, $\mathrm{D}^{*}=\mathrm{D}$.

\section{CSU Equation}

The Colorado State University (CSU) equation (Richardson and Davis 2001), also known as the HEC-18 equation, is

$$
\frac{\mathrm{d}_{\mathrm{se}}}{\mathrm{D}}=2.0 \mathrm{~K}_{3}\left(\frac{\mathrm{y}_{0}}{\mathrm{D}}\right)^{0.35} \mathrm{Fr}^{0.43}
$$

where $\mathrm{K}_{3}$ accounts for the bed forms $\left(\mathrm{K}_{3}\right.$ is 1.1 if $\mathrm{V} / \mathrm{V}_{\mathrm{c}}<1$ or $\left.\mathrm{V} / \mathrm{V}_{\mathrm{c}}>\mathrm{V}_{\mathrm{lp}} / \mathrm{V}_{\mathrm{c}}\right)$. The maximum value for $\mathrm{d}_{\mathrm{se}} / \mathrm{D}$ is capped at 2.4 for $\mathrm{Fr} \leq 0.8$, and at 3.0 for $\mathrm{Fr}>0.8$.

Melville's Equation

Melville's equation (Melville 1997) is a function of $V / V_{c}, D / D_{50}$ and $y_{0} / D$. For a circular pile and uniform sediment, Melville's equation is 


$$
\frac{\mathrm{d}_{\mathrm{se}}}{\mathrm{D}}=\mathrm{K}_{\mathrm{I}} \mathrm{K}_{\mathrm{d}} \mathrm{K}_{\mathrm{yD}},
$$

where $\mathrm{K}_{\mathrm{I}}=\mathrm{V} / \mathrm{V}_{\mathrm{c}}$; if $\mathrm{V} / \mathrm{V}_{\mathrm{c}} \leq 1$ and $\mathrm{K}_{\mathrm{I}}=1$ for $\mathrm{V} / \mathrm{V}_{\mathrm{c}}>1 ; \mathrm{K}_{\mathrm{d}}=0.57 \log \left(2.24 \mathrm{D} / \mathrm{D}_{50}\right)$ if $\mathrm{D} / \mathrm{D}_{50} \leq 25$ and $\mathrm{K}_{\mathrm{d}}=1$ for $\mathrm{D} / \mathrm{D}_{50}>25$; and $\mathrm{K}_{\mathrm{yD}}=2.4$ if $\mathrm{D} / \mathrm{y}_{0}<0.7, \mathrm{~K}_{\mathrm{yD}}=2 \sqrt{\mathrm{y}_{0} / \mathrm{D}}$ if $0.7 \leq \mathrm{D} / \mathrm{y}_{0} \leq 5$ and $\mathrm{K}_{\mathrm{yD}}=4.5\left(\mathrm{y}_{0} / \mathrm{D}\right)$ if $\mathrm{D} / \mathrm{y}_{0}>5$.

\section{Breusers Equation}

Finally, Breusers equation is a function of $\mathrm{V} / \mathrm{V}_{\mathrm{c}}$ and $\mathrm{y}_{0} / \mathrm{D}$, only. For circular piers, the equation is

$$
\frac{\mathrm{d}_{\mathrm{se}}}{\mathrm{D}}=\mathrm{K}_{\mathrm{V}} \tanh \left(\frac{\mathrm{y}_{0}}{\mathrm{D}}\right),
$$

where $\mathrm{K}_{\mathrm{v}}=0$ for $\mathrm{V} / \mathrm{V}_{\mathrm{c}} \leq 0.5, \mathrm{~K}_{\mathrm{v}}=2\left(\mathrm{~V} / \mathrm{V}_{\mathrm{c}}\right)-1$ for $0.5<\mathrm{V} / \mathrm{V}_{\mathrm{c}} \leq 1$ and $\mathrm{K}_{\mathrm{v}}=1$ for $\mathrm{V} / \mathrm{V}_{\mathrm{c}}>1$.

All four equations were evaluated for the conditions of the tests and the percent difference between computed and measured plotted in Fig. (3). All four equations over predict the experimental values for most of the tests. In some cases the over prediction is significant (in excess of 100\%). The average and standard deviations (respectively) of the percentage differences for the four equations are: Sheppard (16.6\% and 18.2\%), CSU (33.1\% and $17.5 \%$ ), Melville (51.7\% and 26.9\%) and Breusers (16.1\% and 28.6\%).

As can be seen from the plots the differences between the equations are significant in some cases. These differences can be even greater for large prototype structures. To illustrate this fact several hypothetical structure, sediment and flow situations are evaluated and the results presented in Table (3).

Table 3. Equilibrium scour depth predictions for hypothetical prototype scale structures.

\begin{tabular}{|c|c|c|c|c|c|c|c|c|c|}
\hline $\begin{array}{c}\mathrm{D} \\
(\mathrm{m})\end{array}$ & $\begin{array}{c}\mathrm{D}_{50} \\
(\mathrm{~mm})\end{array}$ & $\begin{array}{c}\mathrm{y}_{0} \\
(\mathrm{~m})\end{array}$ & $\begin{array}{c}\mathrm{V} \\
(\mathrm{m} / \mathrm{s})\end{array}$ & $\begin{array}{c}\mathrm{V}_{\mathrm{c}} \\
(\mathrm{m} / \mathrm{s})\end{array}$ & $\begin{array}{c}\mathrm{V}_{\mathrm{lp}} \\
(\mathrm{m} / \mathrm{s})\end{array}$ & $\begin{array}{c}\text { Shep } \\
(\mathrm{m})\end{array}$ & $\begin{array}{c}\mathrm{CSU} \\
(\mathrm{m})\end{array}$ & $\begin{array}{c}\text { Mel } \\
(\mathrm{m})\end{array}$ & $\begin{array}{c}\text { Brus } \\
(\mathrm{m})\end{array}$ \\
\hline 10 & 0.2 & 5 & 2.5 & 0.36 & 5.60 & 8.46 & 10.08 & 14.14 & 4.62 \\
\hline 10 & 0.4 & 5 & 2.5 & 0.38 & 5.60 & 8.85 & 10.08 & 14.14 & 4.62 \\
\hline 10 & 1.0 & 5 & 2.5 & 0.57 & 5.60 & 9.31 & 10.08 & 14.14 & 4.62 \\
\hline 10 & 5.0 & 5 & 2.5 & 1.42 & 7.14 & 9.74 & 10.08 & 14.14 & 4.62 \\
\hline 10 & 0.2 & 10 & 2.5 & 0.38 & 7.92 & 8.64 & 11.06 & 20.00 & 7.62 \\
\hline 10 & 0.4 & 10 & 2.5 & 0.40 & 7.92 & 9.20 & 11.06 & 20.00 & 7.62 \\
\hline 10 & 1.0 & 10 & 2.5 & 0.61 & 7.92 & 9.93 & 11.06 & 20.00 & 7.62 \\
\hline 10 & 5.0 & 10 & 2.5 & 1.54 & 7.92 & 11.36 & 11.06 & 20.00 & 7.62 \\
\hline
\end{tabular}




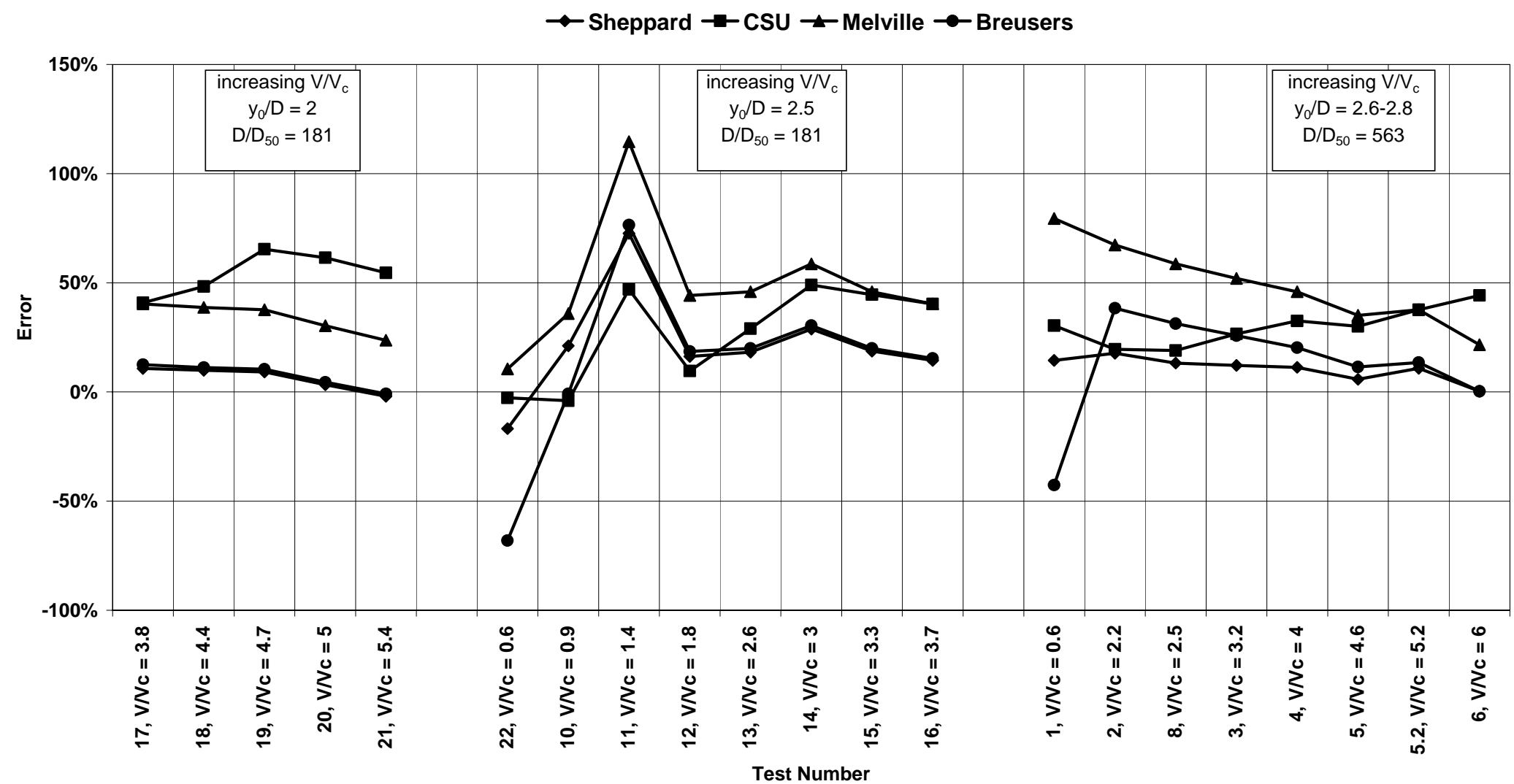

Figure 3. Percent difference between predicted and measured scour depths using four different predictive equations. 


\section{Summary and Conclusions}

The experiments in this study have extended the live-bed local scour depth data set. These live-bed data are consistent with data obtained by Ettema (1980) and Chiew (1984) in showing the decreased dependence of normalized equilibrium scour on $\mathrm{D} / \mathrm{D}_{50}$ at high values of $\mathrm{V} / \mathrm{V}_{\mathrm{c}}$. A possible explanation as to why there is a scour depth dependence on $\mathrm{D} / \mathrm{D}_{50}$ and why this dependence decreases with increased values of this parameter was given by Sheppard (2004). Sheppard's equations, which have already been validated for large structures (up to $0.914 \mathrm{~m}$ diameter) in the clear-water scour range (Sheppard 2003b) yield good results in the live-bed scour range covered by these experiments. Three additional, commonly used, local scour prediction equations were evaluated for the conditions of the experiments. All four predictive equations were evaluated for several hypothetical prototype scale structures and the results found to differ significantly.

\section{Acknowledgements}

The authors thank Rick Renna, Shawn McLemore and Richard Long with the Florida Department of Transportation for supporting this research. Thanks also go to engineer Sidney Schofield, technicians Jim Joiner and Chuck Broward and machinist Vernon Sparkman for assisting with the design and construction of the instrumentation.

Very special thanks to Dr. Bruce Melville and his staff, Jim Beckner and Raymond Hoffmann, for their assistance with the construction of the test structures, flume modifications and the conduct of the experiments. The authors are indebted to University of Auckland graduate students Sjoerd van Ballegooy and Thomas Macdougal Clunie for their diligent and dedicated work in running the tests.

\section{References}

Breusers, H. N. C., Nicollet, G., and Shen, H. W. (1977). "Local Scour around cylindrical piers." J. Hydr. Res., 15(3), 211-252.

Chiew, Y.M. (1984). "Local scour at bridge piers." Rep. No. 355, Dept. of Civ. Engr., University of Auckland, Auckland, New Zealand.

Ettema, R. (1980). "Scour at Bridge Piers" Rep. No. 236, Dept. of Civ. Engr., University of Auckland, Auckland, New Zealand.

Melville, B.W. and Chiew, Y.M. (1999). "Time Scale for Local Scour at Bridge Piers." J. Hydr. Engrg., ASCE, 125(1), pp. 59-65, ASCE.

Melville, B.W. and Coleman, S.E. (2000). Bridge Scour, Water Resources Publications, LLC, Highlands Ranch, CO, 572 pp.

Richardson, E.V. and Davis, S.R. (2001). "Evaluating Scour at Bridges." Publication No. FHWA NHI 01-001, Hydraulic Engineering Circular No. 18, Federal Highway Administration, U.S. Department of Transportation, Washington, D.C.

Sheppard, D. M.(1998). "Conditions of Maximum Local Scour," Compendium of Scour Papers from ASCE Water Resources Conferences, Eds. E.V. Richardson and P.F. Lagasse, September, 1998. 
Sheppard, D. M. (2003a). "Large Scale and Live-Bed Local pier Scour Experiments." Coastal Engineering Technical Report No. 133, Civil and Coastal Engr. Dept., Univ. of FL, Gainesville, Florida.

Sheppard, D. M. (2003b). "Large Scale Clear-water Local Pier Scour Experiments." Coastal Engineering Technical Report No. 131, Civil and Coastal Engr. Dept., Univ. of FL, Gainesville, Florida.

Sheppard, D. M. (2004). "An Overlooked Local Sediment Scour Mechanism." Proceedings of the 83rd Meeting of the Transportation Research Board, Washington D.C., January 11-15, 2004.

van Rijn, Leo C. (1993). Principles of Sediment Transport in Rivers, Estuaries and

Coastal Seas, Aqua Publications, Amsterdam, The Netherlands.

\section{Notation}

$\mathrm{D}=$ circular pile diameter,

$D^{*}=$ effective structure width/diameter $=K_{s} D$,

$\mathrm{D}_{50}=$ median sediment grain diameter,

$\mathrm{d}_{\mathrm{s}}=$ scour depth at the end of the experiment,

$\mathrm{d}_{\mathrm{s}}(\mathrm{t})=$ scour depth as a function of time,

$\mathrm{d}_{\mathrm{se}}=$ equilibrium scour depth,

$\mathrm{Fr}=$ Froude Number $=\sqrt{\mathrm{V} / \mathrm{g} \mathrm{y}_{0}}$,

$\mathrm{K}_{\mathrm{s}}=$ effective diameter shape factor,

$\sigma=$ standard deviation of sediment particle size distribution,

$\mathrm{t}=$ time,

$\mathrm{T}=$ temperature,

Time $=$ test duration $($ Table 1$)$,

$\mathrm{V}=$ depth averaged velocity,

$\mathrm{V}_{\mathrm{c}}=$ sediment critical depth averaged velocity,

$\mathrm{V}_{\mathrm{lp}}=$ live-bed peak scour velocity (velocity where the bed planes out),

$\mathrm{y}_{0}=$ approach water depth. 